\title{
Dyes and biological sources in nineteenth to twentieth century ethnographic textiles from Transylvania, Romania
}

\author{
Irina Petroviciu ${ }^{1 *} \mathbb{D}$, lulia Teodorescu ${ }^{2}$, Florin Albu ${ }^{3}$, Marian Virgolici ${ }^{4}$, Eugenia Nagoda $^{5}$ \\ and Andrei Medvedovici ${ }^{6}$
}

\begin{abstract}
Liquid chromatography with UV-Vis and mass spectrometric detection (LC-DAD-MS) was applied to the identification of dyes and biological sources in samples from nineteenth to twentieth century ethnographic textiles from ASTRA National Museum Complex, Sibiu, Transylvania. The objects are part of the Romanian traditional costume and are among the first to be acquired for the museum collections, around 1905. Oral and written information mention such objects as homemade, with nearby materials, while literature mentions a significant number of local vegetal sources as being used for textile dyeing. The analytical protocol developed, based on the combined use of the UVVis and mass spectrometric detectors to associate the information and distinguish between major and minor dyes, facilitates a clear attribution of the dyes and biological source/sources used. Other techniques, such as X-ray spectroscopy and FTIR-ATR were successfully used to identify inorganic dyes, which may not be detected by LC-DAD-MS, as was the case of Prussian blue. A large number of biological sources was identified in the studied objects, both local and imported. The local sources identified include dyer's broom (Genista tinctoria L.), sawwort (Serratula tinctoria L.), young fustic (Cotinus coggygria Scop.), Rhamnus berries, emodin based dyes (Rhamnus, Rheum, Rumex sp.) and woad (Isatis tinctoria L.), in perfect correlation with literature which states that local dyes were still in use in the period under discussion. Carminic acid containing insects (Dactylopius coccus Costa and Porphyrophora sp.) and redwood type Caesalpinia species should be considered a result of trade. Almost all the natural and synthetic dyes detected are frequently mentioned in a collection of recipes published by the Romanian Academy, in 1914. The richness in colours in belts, the use of insect dyes in shirts decoration and the large amount of cotton in shirts are illustrative for the owners' status. The study provides a better valorisation of the Romanian traditional costume as witness of the rural society at the end of the nineteenth to beginning of the twentieth century and emphasizes the usefulness of chemistry in cultural heritage dedicated applications.
\end{abstract}

Keywords: Natural dyes, Liquid chromatography, Mass spectrometry, Ethnographical textiles, Belts, Shirts, Decoration, Romania

\footnotetext{
*Correspondence: petroviciu@yahoo.com

${ }^{1}$ National Museum of Romanian History (MNIR), Calea Victoriei 12,

030026 Bucharest, Romania

Full list of author information is available at the end of the article
}

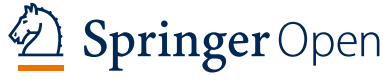

C The Author(s) 2019. This article is distributed under the terms of the Creative Commons Attribution 4.0 International License (http://creativecommons.org/licenses/by/4.0/), which permits unrestricted use, distribution, and reproduction in any medium, provided you give appropriate credit to the original author(s) and the source, provide a link to the Creative Commons license, and indicate if changes were made. The Creative Commons Public Domain Dedication waiver (http://creativecommons.org/ publicdomain/zero/1.0/) applies to the data made available in this article, unless otherwise stated. 


\section{Introduction}

Ethnographical textiles, from which the oldest date back to the second half of the nineteenth century, represent an important part of the Romanian heritage. As witnesses of the rural life in this period, ethnographical textiles have been studied mainly considering artistic, historic and anthropological criteria, with only rare references to the materials used [1-4]. It was only in the last 20 years that more particular studies were dedicated to fibers, techniques and to the biological sources used for dyeing [5-8]. According to the results obtained in the first study dedicated to the identification of natural dyes in ethnographical textiles from Romanian collections, in 1997 [7], local biological sources, imported natural dyes and synthetic dyes co-existed in the mentioned period. The results of the above mentioned work-performed within a joint research between Romanian institutions and the Royal Institute for Cultural Heritage in Brussels (KIK/ IRPA) - is in perfect agreement with literature [9].

In the present study, dye analysis on selected textiles from the same period, preserved in the ASTRA National Museum Complex, Sibiu, Transylvania (Fig. 1) are discussed. The objects (blouses and belts) are part of the Romanian traditional costume and are among the first to be acquired for The Transylvanian
Association for Romanian Literature and the Culture of the Romanian People (ASTRA) collections, around 1905 [10]. ASTRA was a cultural association founded in 1861 in Sibiu, which had an important role in the cultural life and the movement of national awakening for the Romanians in Transylvania, its museum being the predecessor of ASTRA National Museum Complex [10]. Oral and written sources mention such objects as homemade, with nearby materials (wool, hemp, local dye sources). Literature mentions wool and hemp as being used since Neolithic and late Neolithic respectively [5] while silk as being produced in South East Romania, Dobrogea region, since 1384 [11]. Apart from the esthetic value, the colorful handmade embroidery made by natural dyed silk and wool reveal a persons' statute while the use of cotton would indicate dating after 1900 [12]. The nineteenth century belts are worked in a unique technique of Sprang [11].

For late nineteenth century objects, dyes identification is extremely important, if we consider that natural dyes were used since antiquity and mauveine (or mauve), the first synthetic dye was discovered in 1856 [13]. Moreover, detection of specific combinations of natural dyes allows attribution to the most probable biological sources $[14,15]$. If we take into account that

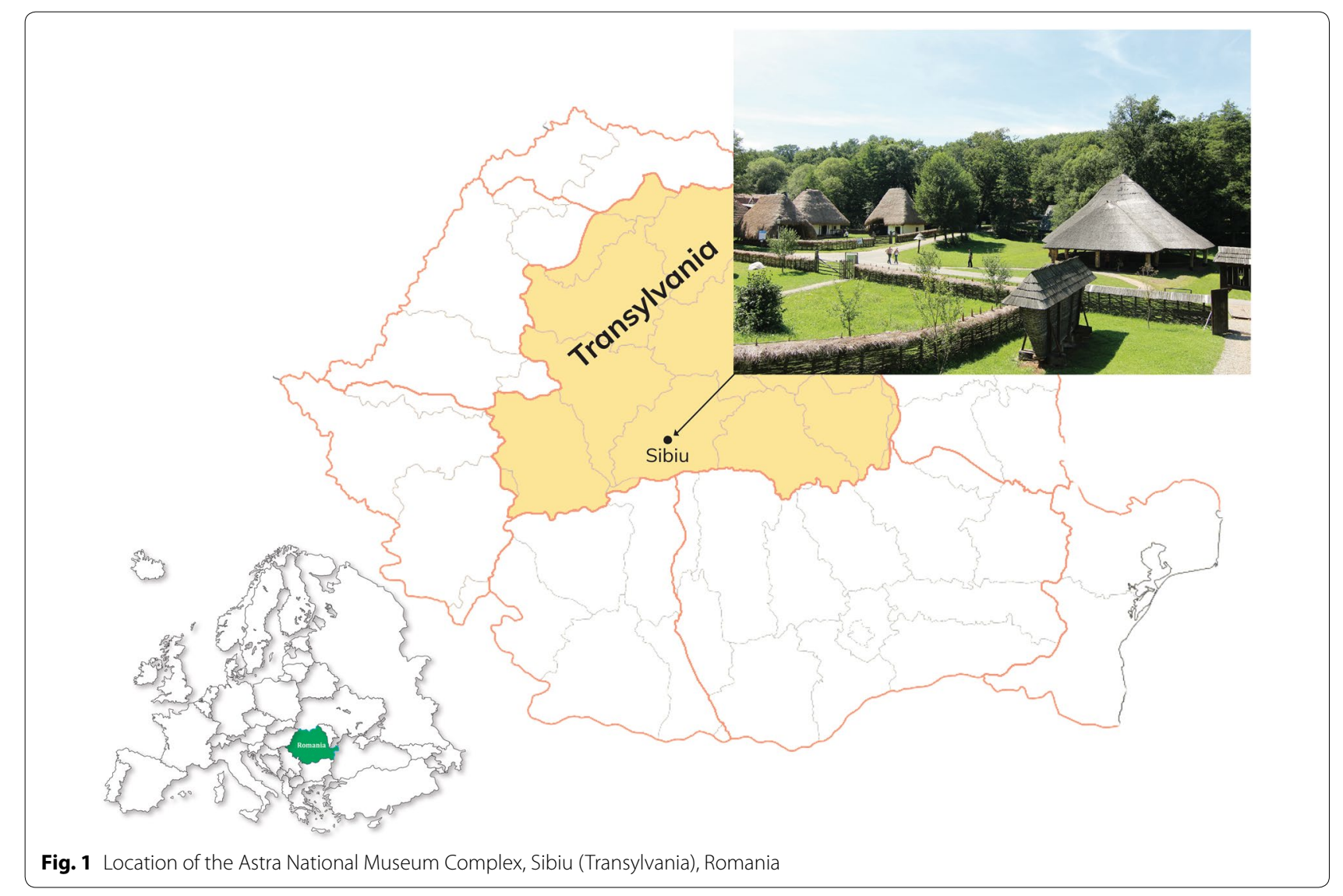


local sources were used before dyes became available through commerce, and that many trade routes are now documented, as being connected to historical events and geographical discoveries, identification of a specific source would be helpful to understand more about the context an object was created.

For several years since its development by Wouters, in 1985 [16], liquid chromatography with UV-Vis (diode array) detection was the standard method for dye analysis [17-20]. More recently, liquid chromatography with UV-Vis and mass spectrometric (MS) detectors became the ideal configuration for natural dyes investigation [21-24]. The use of mass spectrometers brings a new criteria-the molecular ion (for simple MS detectors) and, for MS/MS systems, the product ion scan. Mass spectrometers also allow lower detection limits for most of the dyes used in historical and archaeological textiles, due to the increased sensitivity achieved by selectivity (more often through decreasing the noise level, as a direct result of the induced selectivity) [25]. The MS/MS configurations were also proved to be useful to discover the molecular structure of unknown dyes [26]. In the last years, ultra high pressure liquid chromatography (UHPLC) uses smaller particle size columns to achieve increasingly accurate chromatographic results $[27,28]$.

In the present study, dye analysis were performed by liquid chromatography with UV-Vis and mass spectrometric detection (LC-DAD-MS), according to a procedure described in detail in earlier publications $[29,30]$. The method was applied on a selection of samples from belts and shirts, from the collection of ASTRA Museum Complex, Sibiu, Transylvania.

\section{Materials and methods}

\section{Samples and sample preparation}

Samples about $0.5 \mathrm{~cm}$ long $(\sim 3 \mathrm{mg})$ were taken during the conservation procedures from 7 textiles ( 3 belts and 4 shirts), dated nineteenth to twentieth century, belonging to ASTRA Museum, Sibiu, Romania (Fig. 1). A total of 31 samples were available, 12 from belts and 19 from shirts decoration (Fig. 2). Fibres were first observed under the stereo microscope, at $10-80 \times$ and then non-destructively analysed by attenuated total reflectance infrared spectroscopy (FTIR-ATR). In one case only, when the presence of Prussian blue was suggested by FTIR-ATR, elemental analysis of the coloured fibre was determined by $\mathrm{X}$ ray fluorescence spectrometry (XRF).

Dyes extraction was made by acid hydrolysis, according to the method developed by Wouters [16]. Although limited, as it decomposes glycosides to their parent aglycons in the case of yellow flavonoid dyes [31, 32], this method was preferred because a dedicated database was already in use. $250 \mu \mathrm{L}$ mixture $37 \% \mathrm{HCl} / \mathrm{CH}_{3} \mathrm{OH} / \mathrm{H}_{2} \mathrm{O}$ 2:1:1 ( $/ \mathrm{v} / \mathrm{v})$ were added on each fibre and the mixtures were kept at $100{ }^{\circ} \mathrm{C}$ for $10 \mathrm{~min}$. The solutions were evaporated to dryness in a vacuum desiccator. Each sample was redissolved in $100 \mu \mathrm{L}$ solution $\mathrm{CH}_{3} \mathrm{OH} / \mathrm{H}_{2} \mathrm{O}$ 1:1 (v/v) and centrifuged at 12,000 rpm for $10 \mathrm{~min}$. The supernatants were transferred in chromatographical vials and injected into the chromatographical system. For the visual blue and green samples, a second extraction in $100 \mu \mathrm{L}$ dimethyl sulfoxide (DMSO) was made, and the samples were kept at $80^{\circ} \mathrm{C}$ for $10 \mathrm{~min}$. The two solutions were analysed together. More details on sample preparation and the instrumentation used were described in earlier publications $[29,30]$.

\section{Fibre investigation}

A Nikon SMZ 1000 stereomicroscope was used for fibres observation. For documentation and images collection, the microscope was coupled with a Nikon DSLR camera, model D3100 Kit AF-s 18-55 mm VR DX. Further investigation on the fibres was made by infrared spectroscopy (FTIR-ATR) by using a Bruker Optics Alpha spectrometer equipped with a Platinum ATR single reflection diamond ATR module. Spectra were acquired in the $4000-400 \mathrm{~cm}^{-1}$ domain, with a resolution of $4 \mathrm{~cm}^{-1}$. Spectra collection and data processing were made with a dedicated software, Opus 7.0.

\section{Dye analysis \\ Database}

Dyes were identified according to retention, UV-Vis and mass spectrometric data, as compared to information collected on standards. Analysis of standard dyed fibres (fibres dyed in the laboratory with known biological sources, by following traditional dyeing methods) and information available in literature are the basis of biological sources attribution $[14,15]$. The biological sources of dyes are given in Table 1, while retention, UVVis and mass spectrometric data of the dyes detected, are described in Table 2.

\section{Instrumentation}

Samples were analysed by liquid chromatography with diode array and (triple quadrupole) mass spectrometric detection (LC-DAD-MS). An Agilent 1260 LC system was used, composed of the following modules: quaternary pump (Model G1311C), automatic injector (G1367E) and column thermostat (G1316C). The diode array detector (G4212A) and the triple quadrupole mass spectrometer (G6410B) were serially connected. The latter was using an ESI ionization source (ESI, Model G1948B), operated under negative ion monitoring mode. 

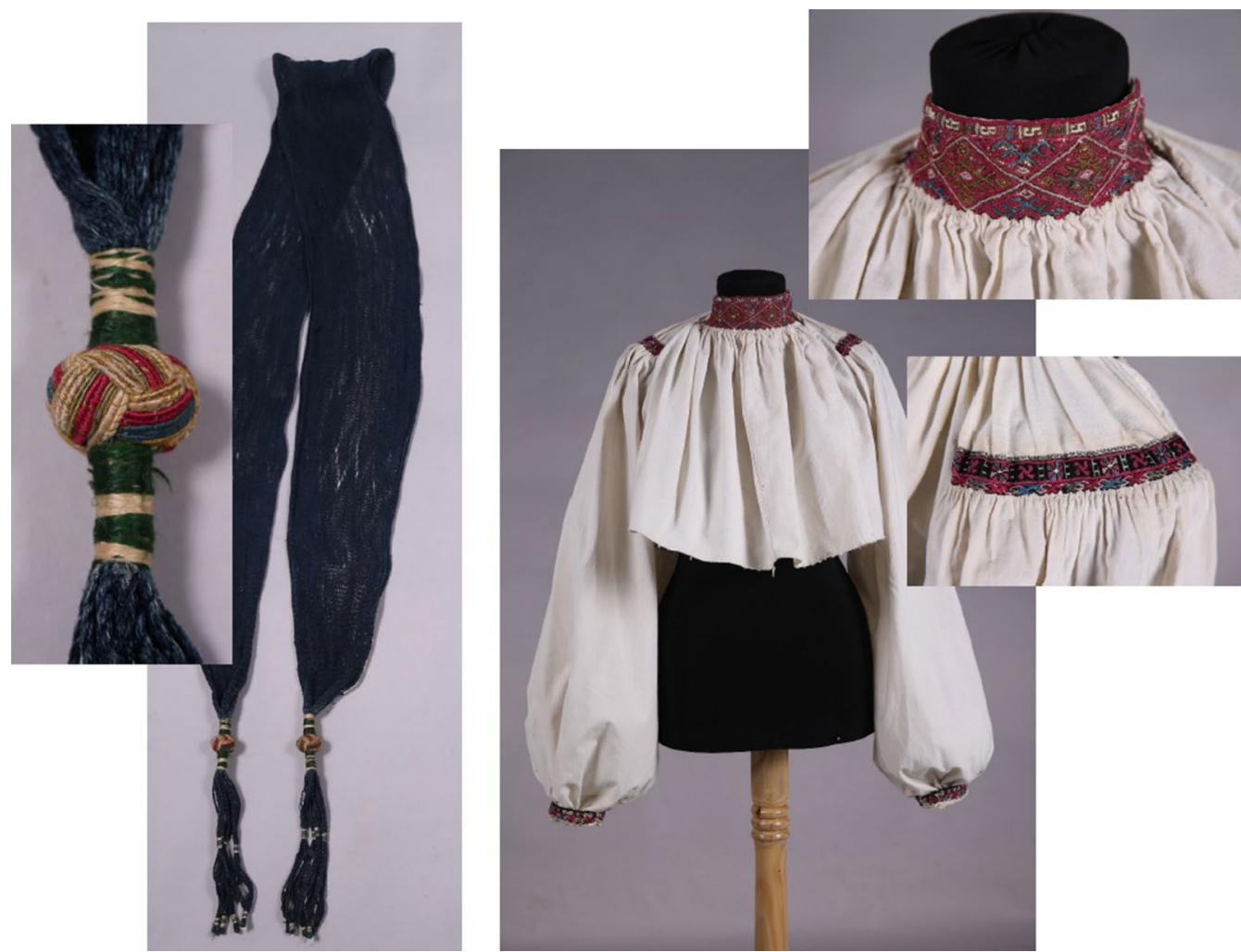

Fig. 2 Examples of objects (belts and shirts with details on decorations) from which 31 dyed fibre samples were withdrawn. Left: Belt 554P, ensemble and detail (the belt is $254 \mathrm{~cm}$ long and $40 \mathrm{~cm}$ wide, the sphere decoration is $4 \mathrm{~cm}$ in diameter). Right: Shirt 20P, ensemble and details (the shirt is $39 \mathrm{~cm}$ long and $75 \mathrm{~cm}$ wide, the sleeve is $37 \mathrm{~cm}$ wide, neck diameter $14 \mathrm{~cm}$ )

\section{Chromatographic separation}

A Zorbax C18 column, $150 \mathrm{~mm} \mathrm{~L} \times 4.6$ i.d. $\times 5 \mu \mathrm{m}$ d.p. was used, thermostated at $40{ }^{\circ} \mathrm{C}$. The mobile phase consisted in a mixture of aqueous $0.2 \%(\mathrm{v} / \mathrm{v})$ formic acid (solvent A) and methanol/acetonitrile (1:1, v/v, solvent B). Gradient elution was applied according to the following profile: at $0 \mathrm{~min}, 15 \%$ solvent $\mathrm{B}$; from 0 to $5 \mathrm{~min}$, linear increase to $25 \%$ solvent $B$; from 5 to $10 \mathrm{~min}$, linear increase to $55 \%$ solvent B; from 10 to 16 , linear increase to $100 \%$ solvent $B$; from min 16 to 18 , constant at $100 \%$ solvent $\mathrm{B}$; and step jump at $15 \%$ solvent $\mathrm{B}$, with a $4 \mathrm{~min}$ re-equilibration step (period between runs). The flow rate was set at $0.8 \mathrm{~mL} / \mathrm{min} .5 \mu \mathrm{L}$ were injected for each sample, from the $100 \mu \mathrm{L}$ volume resulting from sample preparation.

\section{Detection}

UV-Vis spectra were acquired with a DAD detector which was placed between the column and the MS ion source. Spectra were collected over the 190-640 nm range, with a resolution of $2 \mathrm{~nm}$. A triple quadrupole MS detector was used, which was operated in negative ion monitoring mode, with the following ESI operation parameters: drying gas temperature $350{ }^{\circ} \mathrm{C}$; drying gas flow $8 \mathrm{~L} / \mathrm{min}$; pressure of the nebulising gas 40 psi; Vcap $2500(-)$. The triple quadrupole used MS2 type Scan when used as a single MS instrument; the data storage was set on profile and the peak width at 0.07; fragmentor $135 \mathrm{~V} ; \triangle \mathrm{EMV} 400 \mathrm{~V}$; The scanning interval for the mass to charge ratio $(\mathrm{m} / \mathrm{z})$ was between 100 and 600 a.m.u., acceleration voltage on the collision cell: $7 \mathrm{~V}$; Dwell Time $500 \mathrm{~ms}$. When working in the product ion scan mode, the following parameters were used: start mass 50 a.m.u.; end mass 600 a.m.u.

\section{Data processing}

Agilent MassHunter Quantitative Analysis B.06.00 software was used to control the chromatographic system, for data acquisition and processing. The analytical procedure was described in detail in an earlier publication, where an ion trap mass spectrometer was used instead of the triple quadrupole [29]. Each sample was first analysed with single MS detection exploited in the Full Scan mode and the resulted data was processed by extracting chromatograms, according to the molecular ions of the dyes in the database. If necessary, a second 
Table 1 The biological sources discussed in the present study, the corresponding dyes and their abbreviation

\begin{tabular}{|c|c|c|c|}
\hline \multicolumn{2}{|l|}{ Biological source } & \multirow[t]{2}{*}{ Dye component } & \multirow[t]{2}{*}{ Abbreviation } \\
\hline Common name & Latin name(s) & & \\
\hline \multirow[t]{2}{*}{ Berries } & \multirow[t]{2}{*}{ Rhamnus sp. (berries) } & Quercetin & qu \\
\hline & & Kaempferol & $\mathrm{kpf}$ \\
\hline \multirow[t]{4}{*}{ Carminic acid based insects } & \multirow{4}{*}{$\begin{array}{l}\text { Dactylopius coccus } \\
\text { Porphyrophora hameli } \\
\text { Porphyrophora polonica }\end{array}$} & Carminic acid & $\mathrm{ca}$ \\
\hline & & Flavokermesic acid (C glycoside) & dcll \\
\hline & & Flavokermesic acid & $\mathrm{fk}$ \\
\hline & & Kermesic acid & ka \\
\hline \multirow[t]{5}{*}{ Dyer's broom } & \multirow[t]{5}{*}{ Genista tinctoria $\mathrm{L}$. } & Luteolin & lu \\
\hline & & Genistein & ge \\
\hline & & Apigenin & ap \\
\hline & & Chrysoeriol & chry \\
\hline & & Diosmetin & dios \\
\hline Emodin based dye & Rhamnus, Rheum, Rumex sp. & Emodin & em \\
\hline \multirow[t]{2}{*}{ Indigoid dyes } & \multirow[t]{2}{*}{ Indigofera sp/Isatis tinctoria } & Indigotin & ind \\
\hline & & Indirubin & inr \\
\hline \multirow[t]{2}{*}{ Redwood type } & \multirow[t]{2}{*}{ Caesalpinia sp. } & Brazilein & bra \\
\hline & & Soluble redwood (urolithin C) & srw \\
\hline \multirow[t]{4}{*}{ Sawwort } & \multirow[t]{4}{*}{ Serratula tinctoria $\mathrm{L}$. } & Luteolin & lu \\
\hline & & 3-O-methylquercetin & 3-O-methylqu \\
\hline & & Apigenin & ap \\
\hline & & Quercetin & $q u$ \\
\hline Tannin source & Quercus sp. et al. & Ellagic acid & ea \\
\hline \multirow[t]{2}{*}{ Young fustic } & \multirow[t]{2}{*}{ Cotinus coggygria Scop. } & Fisetin & fi \\
\hline & & Sulphuretin & sul \\
\hline \multirow[t]{3}{*}{ Weld } & \multirow[t]{3}{*}{ Reseda luteola $\mathrm{L}$. } & Luteolin & lu \\
\hline & & Apigenin & ap \\
\hline & & Chrysoeriol & chry \\
\hline
\end{tabular}

injection from the sample was made, by using MS/MS detection. In such a case, the first mass analyzer filters the $\mathrm{m} / \mathrm{z}$ of the molecular (or major) ion of compounds according to database, while the second mass analyzer is exploited in the Full Scan mode. In most cases, retention, UV-Vis and mass spectrometric data were used for the major compounds identification. The minor ones, associated in the biological source with the major dyes detected, were only recognized based on retention and mass spectrometric data.

\section{$X$ ray fluorescence spectrometry (XRF)}

A Bruker manufactured S1 TITAN (Model 600) portable XRF spectrometer was used for elemental analysis of sample 20_P3, for which FTIR-ATR suggested the presence of Prussian blue. The system had the following specifications: $4 \mathrm{~W}$ rhodium $(\mathrm{Rh})$ tube $(15-50 \mathrm{kV}$, 5-100 $\mu \mathrm{A}$ ), silicon drift chamber detector (SDD), $5 \mathrm{~mm}$ spot size. The system was used air-path, elemental range $\mathrm{Z}>12(\mathrm{Mg})$.

\section{Results and discussion \\ Blue dyes \\ Belts}

Indigotin was detected in all the three blue samples (3551_P1, 555_P3, 554_P1) from the main material in the belts, identified as hemp (Table 3). The detection of indigotin was based on the UV-Vis data at $255 \mathrm{~nm}$ (Table 2), correlated with retention. It was also confirmed by the presence of its molecular ion $(\mathrm{m} / \mathrm{z}=261$ $[\mathrm{M}-\mathrm{H}]^{-}$) in the chromatogram collected with the mass spectrometer in the Full Scan mode, followed by data processing through Ion Extracted Chromatogram (IEC). As minor compound, the presence of indirubin was only established by the MS detection, as suggested the presence of the molecular ion, $\mathrm{m} / \mathrm{z}=261$ a.m.u., in the FS-IEC, in correlation with retention. Identification of indigotin and indirubin put forward the use of an indigoid dye. Several plants containing indigotin precursors are mentioned in literature [14], from which Indigofera species and Isatis tinctoria (woad) are the most well-known. As the later was cultivated in Europe 
Table 2 Retention, UV-Vis and MS data for the dyes detected in the present study

\begin{tabular}{|c|c|c|c|}
\hline Dye component (abbreviation) & Retention & UV-Vis ${ }^{a}$ & {$[\mathrm{M}-\mathrm{H}]^{-}$} \\
\hline ap & 13.7 & $210 ; 268 ; 336$ & 269 \\
\hline $\mathrm{ca}$ & 8.8 & $226 ; 276 ; 310 ; 494$ & 491 \\
\hline chry & 13.9 & - & 299 \\
\hline dcll & 8.3 & $288 ; 434$ & 475 \\
\hline dios & 14.0 & - & 299 \\
\hline ea & 9.8 & $254 ; 366$ & 301 \\
\hline em & 17.5 & $222 ; 254 ; 266 ; 288 ; 438$ & 269 \\
\hline fi & 11.3 & $206 ; 248 ; 320 ; 360$ & 285 \\
\hline $\mathrm{fk}$ & 13.5 & - & 313 \\
\hline ge & 13.4 & $208 ; 260$ & 269 \\
\hline ind & 16.2 & $238 ; 285 ; 330 ; 610$ & 261 \\
\hline inr & 17.0 & - & 261 \\
\hline ka & 13.4 & - & 329 \\
\hline $\mathrm{kpf}$ & 13.7 & $204 ; 266 ; 366$ & 285 \\
\hline lu & 12.7 & $208 ; 254 ; 266 ; 348$ & 285 \\
\hline 3-O-methylqu & 12.9 & - & 315 \\
\hline qu & 12.7 & $208 ; 254 ; 265 ; 248$ & 301 \\
\hline srw & 10.5 & $258 ; 306 ; 336$ & 243 \\
\hline sul & 12.2 & $256 ; 369$ & 269 \\
\hline Indigo carmine & 11.2 & $250 ; 288 ; 340 ; 615$ & - \\
\hline Prussian blue & \multicolumn{3}{|c|}{ Identified by FTIR/ATR ${ }^{\text {(signal at } 2074 \mathrm{~cm}^{-1} \text { ) and confirmed by the presence of Fe in XRF }}$} \\
\hline
\end{tabular}

Dyes are listed in alphabetical order. At the end, data on the synthetic dyes detected is given. See Table 1 for the natural dyes biological sources and the dyes names

a UV-Vis data is given only for the major dyes (dyes identified by DAD in the present study)

b,c See text, "Results and discussion" section/Blue dyes/Shirts

for a long time and also mentioned in the Romanian literature at the end of the nineteenth century as used for dyeing under the name "drobșor", Isatis tinctoria (woad) should be considered as the most possible indigoid dye.

For the two visual blue silk samples from the belts tassel decorations available for analysis (3551_P3 and 554_P3), indigo carmine was detected based on the UV-Vis data at $255 \mathrm{~nm}$, correlated with retention. Indigo carmine was also detected in a green silk sample (3551_P2), together with natural sources of yellow (which will be discussed in the "Yellow dyes" section). Indigo carmine (Acid Blue 74), a semi-synthetic dye derived from indigo by sulfonation (which makes the compound soluble in water) was first discovered in 1740 [33]. It was identified in several textile objects from the last quarter of the eighteenth century to the beginning of the twentieth century [33].

For the other two visual green silk samples no sources of blue were detected.

\section{Shirts}

Blue organic dyes were detected in 3 visual blue samples available for analysis from the shirts decoration, while in a black sample, Prussian blue, a dark blue pigment, was identified.
Indigotin and indirubin were detected together in one wool sample (44_P3) which indicates that an indigoid dye was used for dyeing. Indigotin alone was present as major dye in two more samples (20_P4 and 20_P5), on silk, from another shirt. In one of them, which has a bluegreen hue, luteolin was also detected, as minor compound. As stated above, Isatis tinctoria (woad) should be considered the most probable dyeing source used for all these samples.

In a visual black sample (20_P3) carminic acid, known as source of red colour, was the only dye present in the UV-Vis and MS chromatograms. Although a search for dyes in the database was made by extracting the chromatograms according to molecular (or major) ions, no other dyes were present in the black sample 20_P3, neither as major nor as minor component. The database contains most of the dyes mentioned in literature as being used in Europe and Minor Asia. However, the presence of Prussian blue, $\mathrm{Fe}_{4}\left[\mathrm{Fe}(\mathrm{CN})_{6}\right]_{3}$ was indicated by the typical carbon-nitrogen bond, at $2074 \mathrm{~cm}^{-1}$ in the attenuated total reflectance infrared spectroscopy (FTIR-ATR) and confirmed by the detection of iron in the elemental analysis by X-ray fluorescence spectrometry (XRF) (Fig. 3). 
Table 3 Information about the objects, samples and the results obtained by dye analysis

\begin{tabular}{|c|c|c|c|c|c|c|c|}
\hline No. & Object & Sample code & Colour & Fibre & Sample location & Dyes detected & Result \\
\hline \multirow[t]{4}{*}{1.} & \multirow{4}{*}{$\begin{array}{l}\text { Belt } \\
3551 \mathrm{P} \\
\text { (ASTRA) }\end{array}$} & 3551_P1 & Blue & Hemp & Bottom & $\underline{\text { ind, inr }}$ & Indigoid dye \\
\hline & & 3551_P2 & Green & $\underline{\text { Silk }}$ & Tassel decoration & qu, kpf, indigo carmine & $\begin{array}{l}\text { Berries from Rhamnus sp. and } \\
\text { indigo carmine }\end{array}$ \\
\hline & & 3551_P3 & Blue & Silk & Tassel decoration & $\underline{\text { indigo carmine }}$ & Indigo carmine \\
\hline & & 3551_P4 & Yellow & $\underline{\text { Silk }}$ & Tassel decoration & $\underline{\text { lu}}$, 3-O-methylqu, ap, qu & Sawwort \\
\hline \multirow[t]{3}{*}{2.} & \multirow{3}{*}{$\begin{array}{l}\text { Belt } \\
555 P \\
\text { (ASTRA) }\end{array}$} & 555_P1 & Green & $\underline{\text { Silk }}$ & Tassel decoration & $\underline{\text { lu, ap}}$, chry & Weld \\
\hline & & 555_P2 & Yellow-orange & $\underline{\text { Silk }}$ & Tassel decoration & $\underline{s r w}$, em, rht, qu & $\begin{array}{l}\text { Emodin based dye and redwood } \\
\text { type }\end{array}$ \\
\hline & & 555_P3 & Blue & Hemp & Interior & $\underline{\text { ind }}$, inr & Indigoid dye \\
\hline \multirow[t]{5}{*}{3.} & \multirow{5}{*}{$\begin{array}{l}\text { Belt } \\
554 \text { S } \\
\text { (ASTRA) }\end{array}$} & 554_P1 & Blue & Hemp & Interior & ind, inr & Indigoid dye \\
\hline & & 554_P2 & Green & Silk & Tassel decoration & $\frac{\text { lu, ge, ap, 3-O-methylqu, chry, }}{\text { dios }}$ & Dyer's broom and sawwort \\
\hline & & 554_P3 & Blue & Silk & Tassel decoration & $\underline{\text { indigo carmine }}$ & Indigo carmine \\
\hline & & 554_P4 & Light red & Silk & Tassel decoration & $\underline{\mathrm{ca}, \mathrm{dcll}}, \mathrm{ka}, \mathrm{fk}$ & $\begin{array}{l}\text { Carminic acid based insect (pos- } \\
\text { sible Dactylopius coccus) }\end{array}$ \\
\hline & & 554_P5 & Yellow & Silk & Tassel decoration & $\underline{\text { fi, sul }}$ & Young fustic \\
\hline \multirow[t]{3}{*}{4.} & \multirow{3}{*}{$\begin{array}{l}\text { Shirt } \\
\text { 27P Bran } \\
\text { (ASTRA) }\end{array}$} & 27_P1 & Brown & Silk & & ea & Tannin source \\
\hline & & 27_P2 & Dark brown & Silk & Shoulder decoration & $\underline{\text { ea }}$ & Tannin source \\
\hline & & 27_P3 & Violet & Silk & Shoulder decoration & $\underline{c a}, \mathrm{dcll}, \mathrm{ka}, \mathrm{fk}, \underline{\mathrm{ea}}$ & $\begin{array}{l}\text { Carminic acid based insect (pos- } \\
\text { sible Porphyrophora hamelii) } \\
\text { and a tannin source }\end{array}$ \\
\hline \multirow[t]{3}{*}{5.} & \multirow{3}{*}{$\begin{array}{l}\text { Shirt } \\
165 \text { P Rasinari } \\
\text { (ASTRA) }\end{array}$} & $165 \_P 2$ & Brown & Silk & Back, bottom & $\underline{\text { ea }}$ & Tannin source \\
\hline & & 165_P3 & Violet & Silk & Back, bottom & $\underline{\mathrm{ca}}, \mathrm{dcll}, \mathrm{ka}, \mathrm{fk}, \underline{\mathrm{ea}}$ & $\begin{array}{l}\text { Carminic acid based insect (pos- } \\
\text { sible Porphyrophora hamelii) } \\
\text { and a tannin source }\end{array}$ \\
\hline & & 165_P4 & Light brown & Silk & Tassel & ea & Tannin source \\
\hline \multirow[t]{6}{*}{6} & \multirow{6}{*}{$\begin{array}{l}\text { Shirt } \\
\text { 44P Rasinari } \\
\text { (ASTRA) }\end{array}$} & 44_P1 & Brown & Silk & Neck decoration & ea & Tannin source \\
\hline & & 44_P2 & & & Shoulder decoration & $\underline{c a}, d c l l, k a, f k, e a$ & $\begin{array}{l}\text { Carminic acid based insect (pos- } \\
\text { sible Porphyrophora hamelii) } \\
\text { and a tannin source }\end{array}$ \\
\hline & & 44_P3 & Blue & Wool & Neck decoration & ind, inr & Indigoid dye \\
\hline & & 44_P5 & Light green & Wool & Shoulder decoration & $\underline{\text { lu }}$ & Luteolin based dye \\
\hline & & 44_P6 & Red & Wool & Neck decoration & $\underline{\mathrm{ca}, \mathrm{dcll}}, \mathrm{ka}, \mathrm{fk}$ & $\begin{array}{l}\text { Carminic acid based insect (pos- } \\
\text { sible Dactylopius coccus) }\end{array}$ \\
\hline & & 44_P8 & Yellow & Silk & Sleeve decoration & $\underline{\text { lu}}$, ap, chry & Weld (Reseda luteola L.) \\
\hline \multirow[t]{7}{*}{7.} & \multirow[t]{7}{*}{$\begin{array}{l}\text { Shirt } \\
\text { 20P (ASTRA) }\end{array}$} & 20_P1 & Pink & Silk & Neck decoration & $\underline{c a}, d c l l, k a, f k$, ea & $\begin{array}{l}\text { Carminic acid based insect (pos- } \\
\text { sible Porphyrophora hamelii) } \\
\text { and a tannin source }\end{array}$ \\
\hline & & 20_P2 & Light pink & Silk & Neck decoration & $\underline{\mathrm{ca}}, \mathrm{ea}$ & $\begin{array}{l}\text { Carminic acid based insect and a } \\
\text { tannin source }\end{array}$ \\
\hline & & 20_P3 & Black & Silk & Shoulder decoration & Prussian blue ${ }^{\mathrm{a}}$, ca & $\begin{array}{l}\text { Prussian blue and carminic acid } \\
\text { based insect }\end{array}$ \\
\hline & & 20_P4 & Blue-green & Silk & Shoulder decoration & ind, lu & $\begin{array}{l}\text { Indigoid dye and a luteolin } \\
\text { based dye }\end{array}$ \\
\hline & & 20_P5 & Blue & Silk & Neck decoration & $\underline{\text { ind }}$ & Indigoid dye \\
\hline & & 20_P6 & Brown & Wool & Neck decoration & - & Natural dyed wool \\
\hline & & 20_P7 & Ochre yellow & Silk & Neck decoration & $\begin{array}{l}\text { lu, ge, ap, 3-O-methylqu chry, } \\
\text { dios }\end{array}$ & Dyer's broom and sawwort \\
\hline
\end{tabular}




\section{Yellow dyes}

Belts

A large variety of flavonoid dye sources were detected in the three visual yellow (including one with an orange hue) and three visual green samples from the belts decoration.

The presence of luteolin as major dye was attested in three samples (3551_P4, 555_P1, 554_P2) based on retention, UV-VIS spectra and MS (FS-IEC) spectra (see Table 2 for these values). Luteolin, together with apigenin, are present in many plants, from which three played an important role in textile dyeing: weld (Reseda luteola L.), sawwort (Serratula tinctoria L.) and dyer's broom (Genista tinctoria L.). In order to clearly distinguish between them, identification of other dyes is necessary: chrysoeriol (in the absence of genistein) for weld, 3-O-methylquercetin for sawwort and genistein for dyer's broom. Recent studies also demonstrated that, for the latter, both chrysoeriol and diosmetin should be expected [27]. In the present group of samples, identification of apigenin as major dye and chrysoeriol as minor
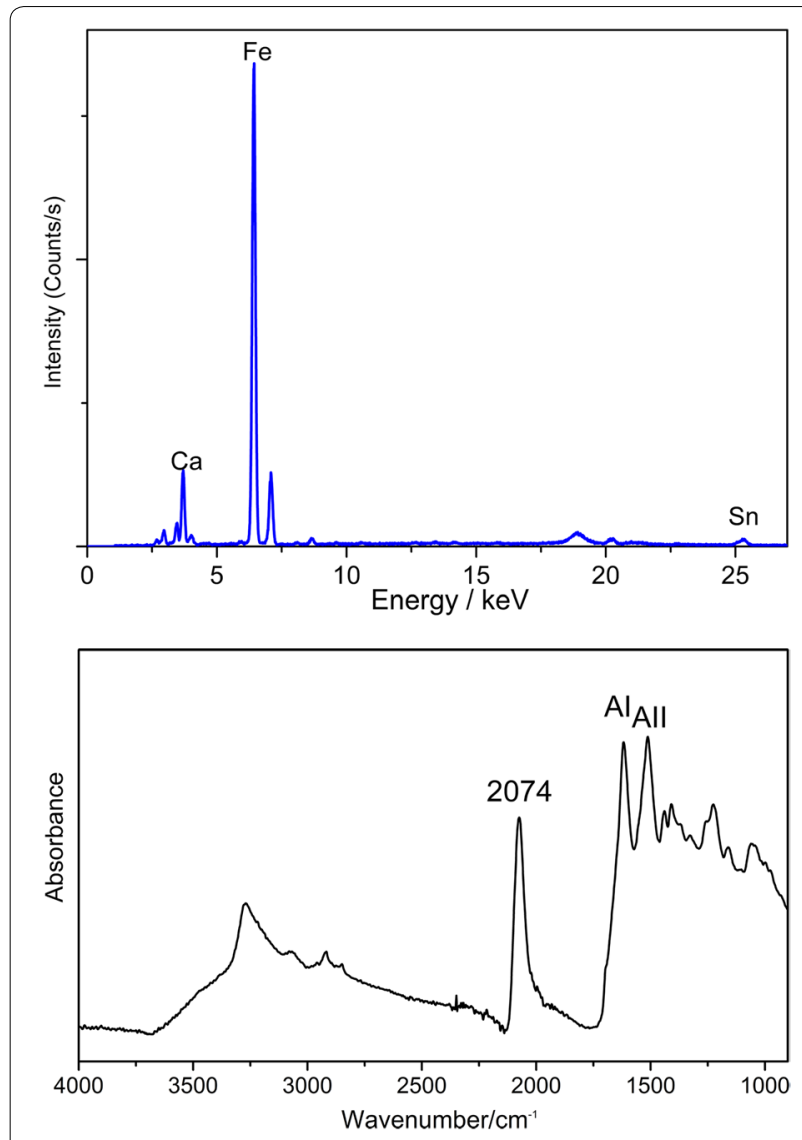

Fig. 3 ATR-FTIR spectrum illustrating the presence of Prussian blue $\left(\mathrm{Fe}_{4}\left[\mathrm{Fe}(\mathrm{CN})_{6}\right]_{3}\right)$, through the presence of the typical vibration of the $\mathrm{C}-\mathrm{N}$ bond, at $2074 \mathrm{~cm}^{-1}$. The main protein bands, amide $A\left(A_{A}\right)$ $\left(3269 \mathrm{~cm}^{-1}\right)$, amide $B\left(A_{B}\right)\left(3066 \mathrm{~cm}^{-1}\right)$, amide $I\left(A_{1}\right)\left(1618 \mathrm{~cm}^{-1}\right)$, amide $\|\left(A_{\|}\right)\left(1512 \mathrm{~cm}^{-1}\right)$ are also evidenced one, in one sample (555_P1), certifies the use of weld (Reseda luteola L.). As in the case of other minor dyes, chrysoeriol was only detected by MS, FS-IEC according to its molecular ion, $\mathrm{m} / \mathrm{z}=299$ a.m.u. In one other case (3551_P4), apigenin as well as 3-O-methylquercetin were identified as minor dyes which suggests the use of sawwort (Serratula tinctoria L.). Detection of quercetin as minor dye comes to reinforce this supposition [34, 35]. The presence of the three dyes was put forward only by the MS detection, based on the presence of the molecular ions $\mathrm{m} / \mathrm{z}=269$ a.m.u., $\mathrm{m} / \mathrm{z}=315$ a.m.u. and $\mathrm{m} / \mathrm{z}=301$ a.m.u., in the FS-IECs. According to literature [35], the acid hydrolysed extract of sawwort contains the flavones luteolin and apigenin and flavonols quercetin and kaempferol, the two later being susceptible to photo-degradation. 3-O-methylquercetin should be thus considered a marker compound, present in sawwort aged samples, together with luteolin and apigenin. For the other sample where luteolin was detected (554_P2), genistein and apigenin were present as major dyes (retention, UV-VIS at $255 \mathrm{~nm}$ and MS), together with luteolin, while 3-O-methylquercetin, chrysoeriol and diosmetin, were minor components (not present in the UV-VIS chromatogram). The presence of the 6 dyes ( 3 major and 3 minor) suggest that a combination of dyer's broom (Genista tinctoria L.) and sawwort (Serratula tinctoria L.) was used for dyeing. This statement is reinforced by the ratio between genistein and apigenin, two dyes with the same molecular weight ( $\mathrm{Mw}=270, \mathrm{~m} / \mathrm{z}=269$ a.m.u. in negative ion mode), which makes them comparable in the IECs. Analysis, performed on several samples where dyer's broom was identified as a unique dyeing source, showed that genistein is present in a larger amount as compared to apigenin, while in the present sample it is the opposite. This could be explained by the extra amount of apigenin, coming from sawwort (Fig. 4). Although the last two samples discussed (3551_P4 and 554_P2) have a visual green colour, no source of blue dyes was detected which would indicate that more probable metal mordants were used to give the fibre a green hue.

Quercetin and kaempferol were detected, as major dyes, together with indigo carmine, in one green sample (3551_P2, also mentioned above as containing blue dyes). The presence of the two flavonoid dyes was established by both UV-VIS data at $255 \mathrm{~nm}$ and MS data (FS-IEC of the molecular ions, $\mathrm{m} / \mathrm{z}=301$ a.m.u. and $\mathrm{m} / \mathrm{z}=285$ a.m.u.), in correlation with retention and demonstrate the use of berries from Rhamnus species.

In a visual yellow-orange sample (555_P2), emodin, rhamnetin and "soluble redwood" (also called "type C", $\mathrm{m} / \mathrm{z}=243)[36,37]$ were detected as major dyes and quercetin as minor dye (Fig. 5). As for the other major dyes, the presence of emodin, rhamnetin and "soluble 
redwood" was put forward by the UV-Vis and MS detectors, while the identification of quercetin was only made by MS data. Emodin (m/z=269 a.m.u.), an anthraquinone dye, may be found in Rhamnus bark, Rheum and Rumex species. Recent studies, performed on Rhamnus frangulae bark and berries, showed that, for the former, mainly emodin together with rhamnetin and quercetin in less amount should be expected [38], which is exactly the case in our study. "Soluble redwood" is a marker for the use of redwood (Caesalpinia species) [17], which could still be identified in redwood dyeing samples when brazilein, the main compound in Caesalpinia species, is too hardly degraded to be identified. This marker compound was recently identified as the benzochromenone urolithin $C$ [39]. Although light fugitive, redwood is a source of red dyes, which would explain the orange hue of sample 555 P2. According to the dyes detected, sample 555_P2 was dyed with a combination of emodin based dye (bark of Rhamnus, Rheum or Rumex species) and redwood (Caesalpinia species).

Fisetin and sulphuretin were detected as major dyes in a visual yellow sample (554_P5) from a belt decoration (Fig. 6). Their presence is suggested by the UV-Vis spectra and MS data (molecular ions of $\mathrm{m} / \mathrm{z}=285$ a.m.u. and $\mathrm{m} / \mathrm{z}=269$ a.m.u. in the respective FS-IECs), correlated with retention. According to literature, the combination of the two dyes suggests the use of young fustic (Cotinus coggygria).

\section{Shirts}

Luteolin was detected as major dye component in three samples (44_P5, 44_P8 and 20_P7) from shirts decorations, in all cases being accompanied by apigenin, which is major dye in 44_P8 and minor, in 20_P7. Chrysoeriol was detected as minor compound in one of these samples (44_P8) which confirm the use of weld (Reseda luteola L.). In one other sample (20_P7), genistein, chrysoeriol, diosmetin and 3-O-methylquercetin were detected (as minor dyes), which indicate that a combination of dyer's broom (Genista tinctoria L.), and sawwort (Serratula tinctoria L.) was responsible for the colour. For sample 44_P5, where luteolin was also detected, no other dyes were present, which made impossible the identification of the dyeing source.

\section{Red dyes \\ Belts}

Carminic acid was identified by both UV-Vis and MS detectors in a light red sample (554_P4) from a belt decoration, the only red sample available from the belts decoration (Fig. 7, left). Its presence was suggested by the UV-Vis spectra correlated with retention and confirmed by the molecular ion $\mathrm{m} / \mathrm{z}=491$ a.m.u., in the FS-IEC.
Although considered a minor component in carminic acid containing insects, flavokermesic acid $\mathrm{C}$ glycoside, also called dcII [26], was identified in sample 554_P4 by both UV-Vis and MS detectors $(\mathrm{m} / \mathrm{z}=475$ a.m.u. in the FS-IEC), which would qualify it as major dye. In the same sample, flavokermesic and kermesic acids were identified as minor components as suggests the presence of their molecular ions, $\mathrm{m} / \mathrm{z}=313$ a.m.u. and $\mathrm{m} / \mathrm{z}=329$ a.m.u., in the FS-IECs. Carminic acid is the main dye component in Porphyrophora species-originary from the Old World and in Dactylopius coccus (Mexican Cochineal), from the New World. Porphyrophora polonica (Polish carmine scale insect) and Porphyrophora hamelii (Armenian carmine scale insect) are the most well known representatives of their species and have a large geographical distribution, from Switzerland, Germany and Czech Republic to Russia, Kazakhstan and Mongolia [14]. Dactylopius coccus may be found in Mexico, South America and the Canary Islands [14]. Dc II, flavokermesic and kermesic acids co-exist, in various amounts, in all the above-mentioned insect dyes, so that identification of the biological source down to the species level becomes a difficult task. Extremely valuable methods to distinguish between the species, according to the semiquantitative evaluation of the ratio between the three dye components were established by Wouters and Verhecken in 1989 [40, 41] and Serrano et al. in 2015 [42]. Although, in our case, it was not possible to reproduce any of these methods, as they are based on many analysis on standard dyed fibres (fibres dyed in the laboratory according to historical recipes), a simple estimation is possible, even on the limited number of samples analysed in our laboratory. Analysis performed on samples dyed with Porphyrophora species and Dactylopius coccus showed that, for the same amount of sample, the presence of dcII could be clearly observed, with both UV-Vis and MS detectors, for samples dyed with Mexican Cochineal, while it is completely absent in those where Porphyrophora species were used (Fig. 7). Consequently, identification of dcII (flavokermesic acid $\mathrm{C}$ glycoside) as major dye, together with carminic acid, and having kermesic and flavokermesic acids as minor dyes, suggest that Dactylopius coccus (Mexican Cochineal) was used for dyeing the light red sample 554_P4.

\section{Shirts}

Carminic acid was detected as major dye component in all 6 samples (27_P3, 165_P3, 44_P2, 44_P6, 20_P1, 20_P2) which have a visual red, light red or violet colour from the shirts decoration. As already mentioned, it was also detected in the black sample (20_P3) where Prussian blue was identified (see blue dyes). Except for the light red sample (20_P2), dc II, kermesic and flavokermesic 


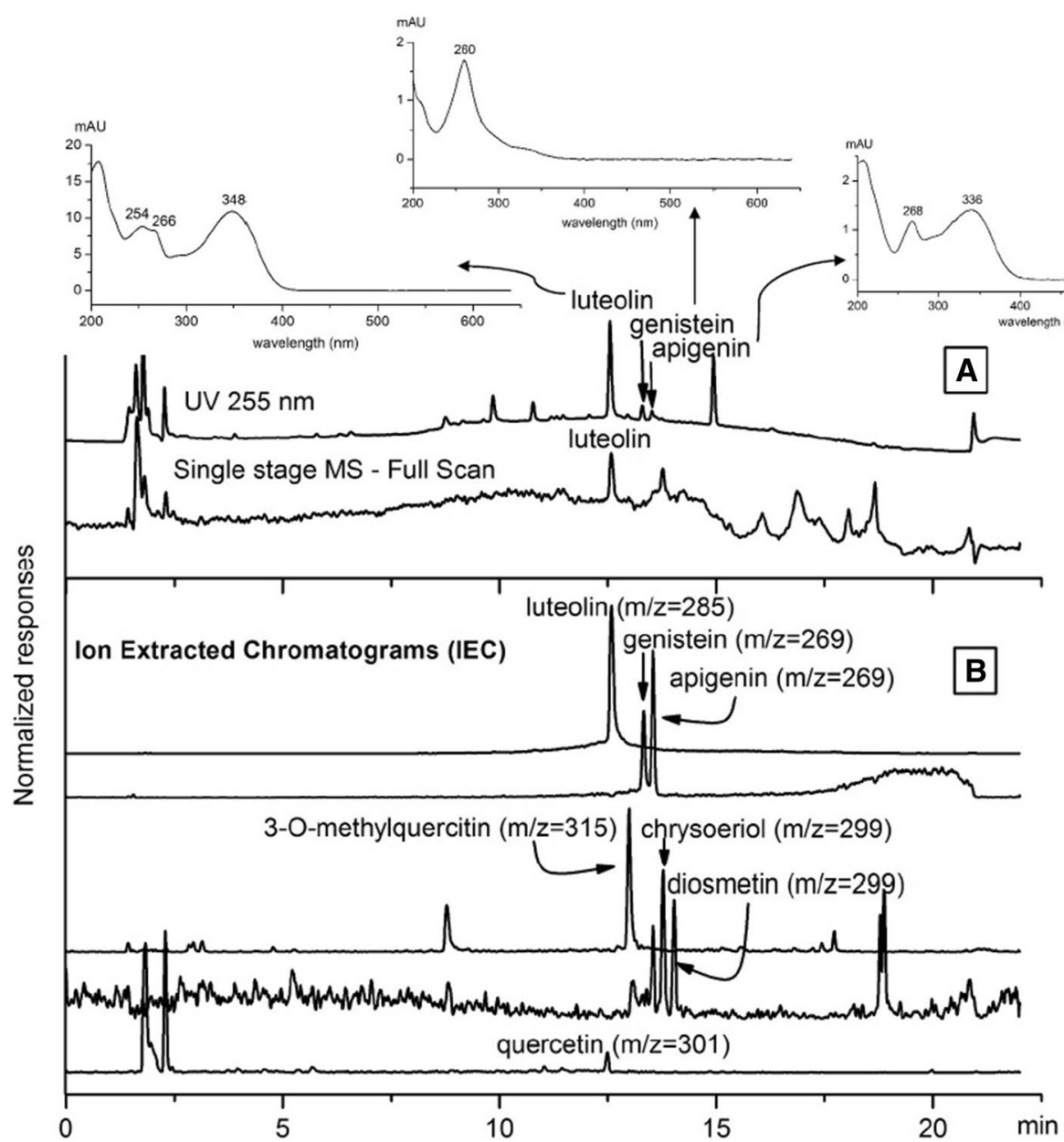

Fig. 4 UV-Vis spectrum, UV chromatogram ( $255 \mathrm{~nm}$ ), total ion current (TIC) chromatogram (resulting after single stage full scan MS detection) and ion extracted chromatograms ( $\mathrm{m} / \mathrm{z}=285,269,299,301,315$ a.m.u.) indicating a combination of dyer's broom (Genista tinctoria L.) and sawwort (Serratula tinctoria L.) being responsible for the colour in sample 554_P2 from belt decoration

acids were also detected (see the discussion above). Considering the detection of dc II as major dye as criteria for the attribution of Dactylopius coccus (Mexican Cochineal), the above mentioned would be the most possible dye source for sample 44_P6. Contrarily, the absence of dc II from the UV-Vis chromatogram, although present in the FS-IEC according to $\mathrm{m} / \mathrm{z}=475$, would indicate the use of Porphyrophora species. Moreover, according to literature and confirmed by analysis performed on standard dyed fibres, kermesic acid is a major dye component in Porphyrophora polonica (Polish carmine scale insect) and a minor one in P. hamelii (Armenian carmine scale insect). Consequently, $P$. hamelii would be responsible for dyeing in samples 27_P3, 165_P3, 44_P2, and 20_P1. No attribution could be made for sample 20_P2, where only carminic acid was identified. For all the samples where dyeing was attributed to P. hamelii, as well as in the sample where only carminic acid was detected, ellagic acid was also present, which suggests the use of tannin sources.

Detection of tin, by XRF analysis, in the black wool sample 20_P3, where Prussian blue and carminic acid were responsible for dyeing, suggests the use of tin chloride as mordant for the insect dye dyeing. Literature mentions that tin was used as mordant for Mexican Cochineal dyeings from the seventieth century [14], which would indicate that Dactylopius coccus (Mexican Cochineal) was used for dyeing in this sample.

\section{Tannins}

Belts

No tannins were identified in the samples available from belts decoration. 


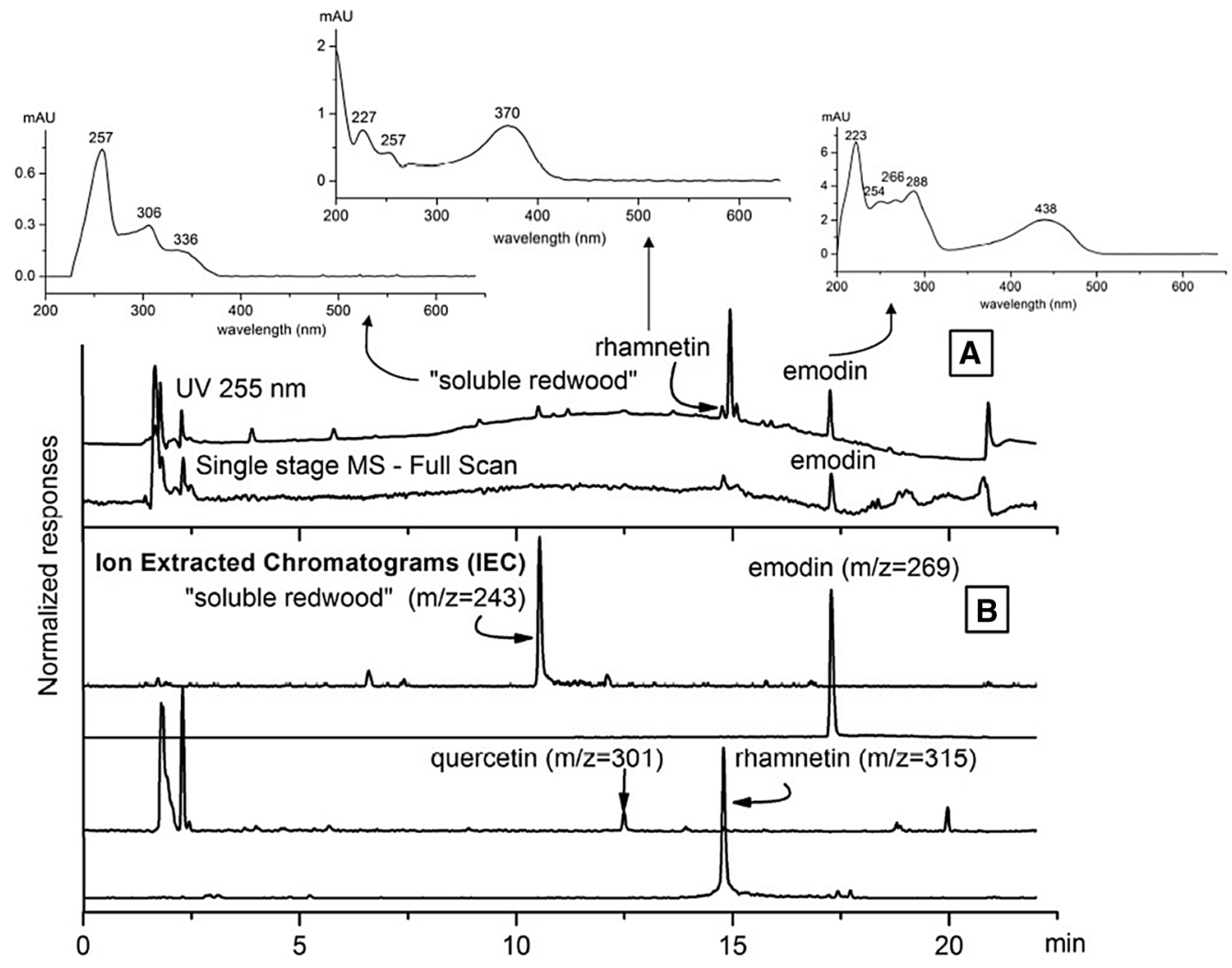

Fig. 5 UV-Vis spectra, UV chromatogram $(255 \mathrm{~nm}$ ), total ion current (TIC) chromatogram (resulting after single stage full scan MS detection) and ion extracted chromatograms ( $\mathrm{m} / \mathrm{z}=243,269,301,315$ a.m.u.) illustrating the presence of emodin, rhamnetin and "soluble redwood" (as major dyes) and quercetin (as minor dye) in the analyzed sample (555_P2)

\section{Shirts}

Ellagic acid was detected in 10 silk samples (27_P1, 27_P2, 27_P3, 165_P2, 165_P3, 165_P4, 44_P1, 44_P2, 20_P1, 20_P2) from shirts decoration, which suggests the use of tannin sources. With 3 exceptions (44_P2, 20_P1, 20_P2), its presence was evidenced by the UVVis spectra, correlated with retention and confirmed by the molecular ion $\mathrm{m} / \mathrm{z}=301$ a.m.u. in the FS-IECs, which qualifies ellagic acid as major dye. These features correspond to the brown samples, where it was the only component identified, and the red and violet samples where it accompanies Armenian carmine scale insects. In the other cases, mostly characterized as light red, it is only a minor source, identified by MS data. For the cases where no other biological sources were used, tannins should be considered as source of colour (very probable with an iron mordant). Many such dyeing recipes describing the use of tannins with iron mordant to achieve grey, brown or black colours are mentioned in literature [14, 15]. By contrary, detection of ellagic acid in the presence of carminic acid insect dyes suggests that tannins were used for silk weighting $[14,15]$.
Discussion about the dyes and biological sources detected A large number of biological sources was identified in the belts and shirts decoration, which is well correlated with literature which states that natural dyes were still in use in late nineteenth to early twentieth century, when synthetic dyes were already available [1,9]. Woad (Isatis tinctoria L.), dyer's broom (Genista tinctoria L.), sawwort (Serratula tinctoria L.), young fustic (Cotinus coggygria Scop.), Rhamnus berries and emodin based dyes (Rhamnus, Rheum, Rumex sp.) are local sources while carminic acid containing insects (Dactylopius coccus Costa and Porphyrophora sp.) and Caesalpinia species are a consequence of trade. Weld (Reseda luteola L.) is a rare plant on the Romanian territory, in contrast to its relative, Reseda lutea L., more frequent but poorer in dyes [14]. Consequently, the detection of weld in belts and shirts decoration should be also considered a result of commerce.

Most of the biological sources identified in the present study, with reference to Transylvania (western part of Romania), were also detected in previous work on ethnographical textiles from Moldavia and Wallachia (Southern and Eastern parts of Romania, see Fig. 1), 


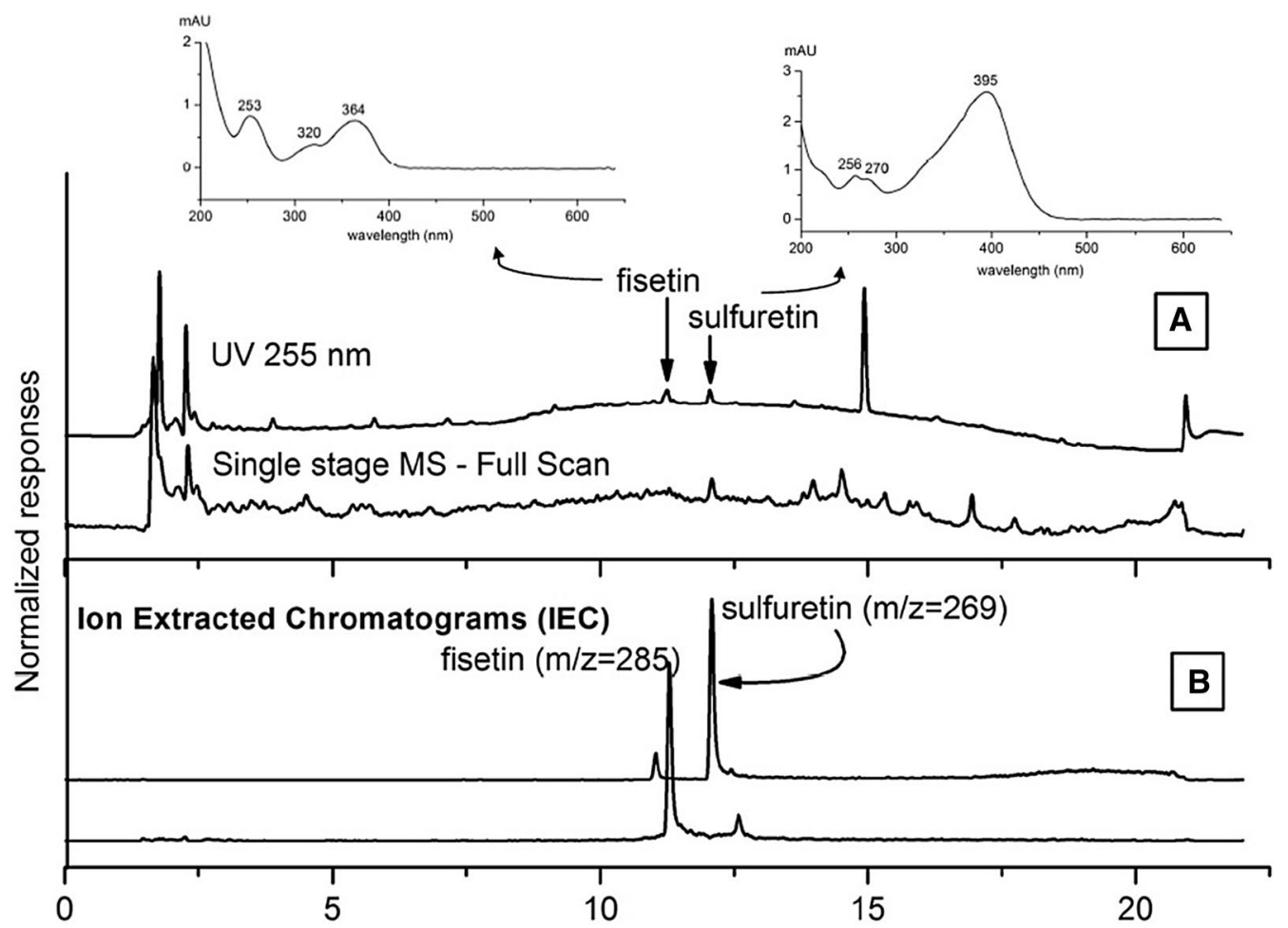

Fig. 6 UV-Vis spectra, UV chromatogram $(255 \mathrm{~nm}$ ), Total lon Current $(\mathrm{TIC})$ chromatogram (resulting after single stage full scan MS detection) and ion extracted chromatograms ( $\mathrm{m} / \mathrm{z}=285,269$ a.m.u.) illustrating the presence of fisetin and sulfuretin as major dyes in a visual yellow sample (554_P5) from a belt decoration

from the same period [7]. Although difficult to be translated in a modern language, valuable information about the art of dyeing, at the end of the nineteenth century and beginning of the twentieth century, is offered by a collection of recipes published by the Romanian Academy in 1914, with reference to Moldavia and Wallachia [9]. Written with the intention to keep alive the memory of the declining art by putting together the existing recipes, the book allows us understand which were the natural and synthetic dye sources and how frequently they were used. For example, dyer's broom ("drobiță", "droghiță"), a local spontaneous plant, appears in more than $60 \%$ of the recipes where yellow dyes are concerned, which qualifies it as the most frequent source of yellow. Other recipes describe the use of various local sources - including the ones identified in the present study dedicated to dyes in belts and shirts decoration in Transylvania: sawwort ("gălbinare", "șoldeală"), young fustic ("scumpie"), Rhamnus berries ("verigariu"), emodin based dyes ("crușinn"), woad ("drobșor"). A careful reading of the recipes which describe "cârmâz" in association with tin reveals the use of Mexican Cochineal (Dactylopius coccus) as imported natural source. Dyeing with Prussian blue ("lulachiu") is also described, although the respective recipes only refer to dyeing in blue and green. The only dyes detected in the present study for which no reference was found in the book are weld (Reseda luteola L.), redwood type (Caesalpinia species) and indigo carmine [9].

\section{Conclusions}

Several biological sources were identified in belts and shirts decoration from Transylvania, dating from late nineteenth to early twentieth century. Most of them, such as dyer's broom (Genista tinctoria L.), sawwort (Serratula tinctoria L.), young fustic (Cotinus coggygria Scop.), Rhamnus berries, emodin based dyes (Rhamnus, Rheum, Rumex sp.) should be considered local sources while others were imported. The latter include redwood type (Caesalpinia sp.) and carminic acid containing insects (Dactylopius coccus Costa and Porphyrophora sp.). Weld (Reseda luteola L.), also detected in two cases, is considered a rare plant in Romania, which indicates its presence to be a result of commerce. Woad (Isatis tinctoria L.) is mentioned as local but it is not possible to establish, based on the existing methods, if it or imported indigo was used in hemp belts or wool and silk belts and shirts decoration. Early synthetic 

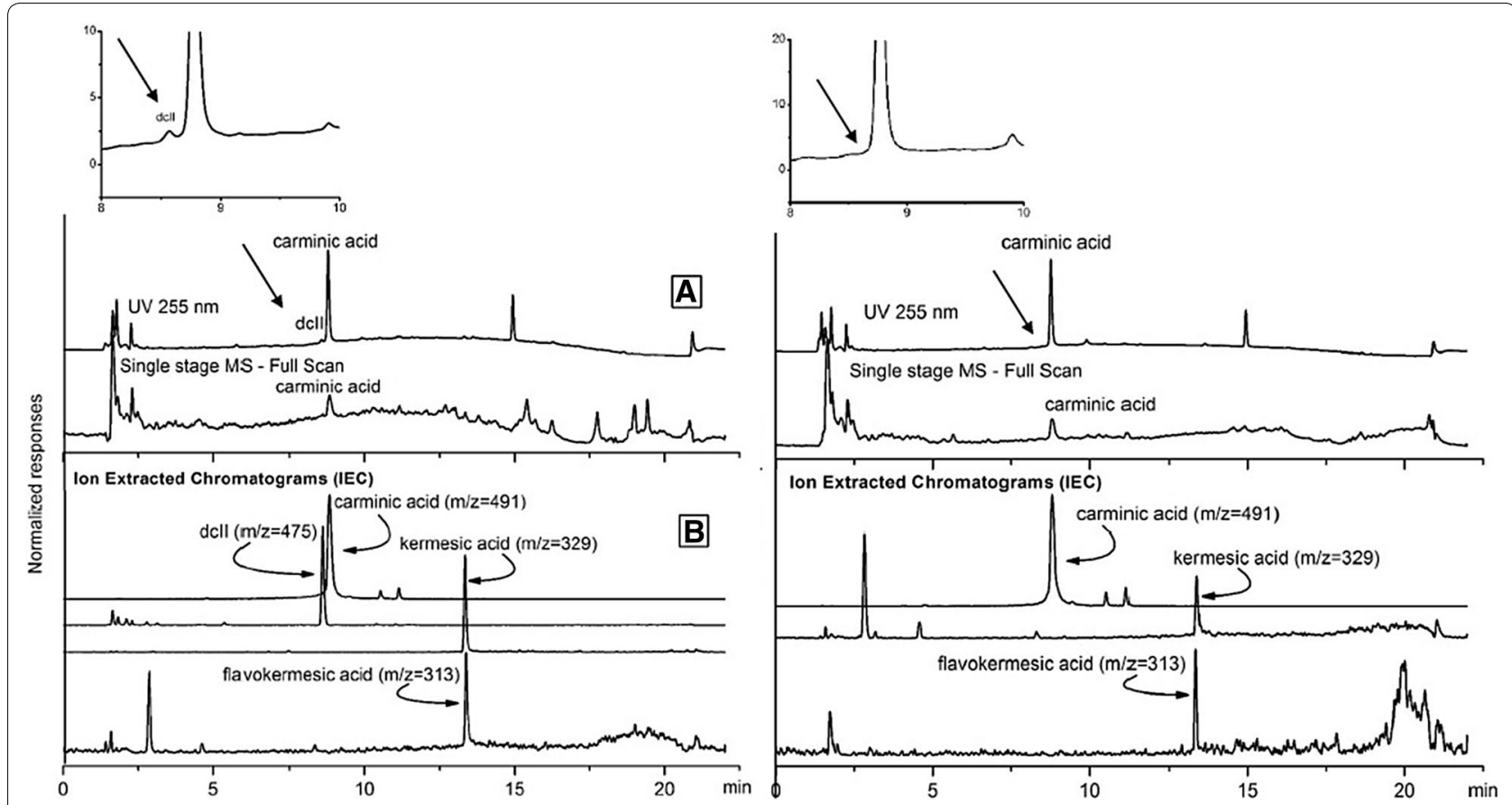

Fig. 7 UV-Vis spectrum, UV chromatogram ( $255 \mathrm{~nm}$ ), total ion current (TIC) chromatogram (resulting after single stage full scan MS detection) and ion extracted chromatograms ( $\mathrm{m} / \mathrm{z}=313,329,475,491$ a.m.u.) indicating the presence of dcll (flavokermesic acid C glycoside) and carminic acid (as major dyes), together with kermesic and flavokermesic acids (as minor dyes), suggesting Dactylopius coccus (Mexican Cochineal) as dyeing agent for the light red sample 554_P4

dyes, such as indigo carmine and Prussian blue were also detected. The interest to obtain a large variety of hues in belts decoration may be deduced from the number of flavonoid dyeing sources detected, in contrast to the red and brown dominant colours in shirts decoration, for which almost only carminic acid based insects and tannin sources were used.

As compared with earlier results on ethnographical textiles in Moldavia and Wallachia from the same period $[7,8]$, it could be stated that the same natural dye sources were detected in textiles from the three provinces. However, at a closer look, the large palette of colours found in only 10 samples from Transylvanian belts decoration is obviously remarkable.

Although the number of synthetic dyes detected is too low to draw any conclusion, it is worth to underline that Prussian blue was only detected in textiles from Transylvania. All the results obtained are in perfect agreement with literature, if we consider that almost all the natural and synthetic dyes detected are frequently mentioned in a collection of recipes published by the Romanian Academy, in 1914 [9]. The richness in colors in belts, the use of insect dyes in shirts decoration and the large amount of cotton in shirts are illustrative for the owners status and for the interest of ASTRA (Association) in 1905, to collect highest level objects for their museum.
The analytical protocol developed, based on the combined use of the UV-Vis and mass spectrometric detectors to associate the information and distinguish between major and minor dyes, facilitates a clear attribution of the dyes and biological source/sources used. Other techniques, such as X-ray spectroscopy and FTIR-ATR were successfully used to identify inorganic dyes, which may not be detected by LC-DAD-MS, as was the case of Prussian blue.

Scientific certification of the objects value together with confirmation of dyeing sources in a collection of recipes published 100 years ago provide a better valorisation of the Romanian traditional costume as witness of the rural society at the end of the nineteenth to beginning of the twentieth century and emphasizes, once more, the usefulness of chemistry in cultural heritage dedicated applications.

\section{Abbreviations}

a.m.u.: atomic mass unit; ATR: attenuated total reflectance; DAD: diode array detection; FS: full scan mode; FTIR: Fourier transform infra red spectrometry; HPLC: high performance liquid chromatography; UHPLC: ultra high pressure liquid chromatography; IEC: ion extracted chromatogram; $\mathrm{m} / \mathrm{z}$ : mass to charge ratio; MS: mass spectrometry; MS/MS: tandem MS spectrometry; XRF: $X$ ray fluorescence spectrometry. 


\section{Authors' contributions}

IP and IT designed the research; IT performed sampling and provided data about the objects; MV provided the necessary instrumentation and assisted IP during sample preparation; FA and AM set up, together with IP, the LCDAD-MS analytical protocol and provided all the support for LC and MS data acquisition and procession; EN assisted the team with information about local and imported vegetal dyeing sources. All authors read and approved the final manuscript.

\section{Author details}

${ }^{1}$ National Museum of Romanian History (MNIR), Calea Victoriei 12, 030026 Bucharest, Romania. ${ }^{2}$ The ASTRA National Museum Complex, Piata Mica 11, 550182 Sibiu, Romania. ${ }^{3}$ Agilrom Scientific SRL, Bucharest, Sos. Pipera-Tunari 1H, 077190 Voluntari, Ilfov, Romania. "Horia Hulubei" National Research Institute for Physics and Nuclear Engineering, IRASM, Str. Reactorului 30, Magurele, Romania. ${ }^{5}$ University of Bucharest, "Dimitrie Brândză" Botanical Garden, Sos. Cotroceni 32, 060114 Bucharest, Romania. ${ }^{6}$ Department of Analytical Chemistry, University of Bucharest, Faculty of Chemistry, Sos. Panduri 90, 050663 Bucharest, Romania.

\section{Acknowledgements}

The authors are grateful to Agilrom Scientific SRL Romania and to IRASM Department in "Horia Hulubei" National Research Institute for Physics and Nuclear Engineering, IRASM, Romania for providing access to the analytical instrumentation and sample preparation facilities. They also express their gratitude to Zizi lleana Balta and Gheorghe Niculescu, who did the XRF analysis.

\section{Competing interests}

The authors declare that they have no competing interests.

\section{Availability of data and materials}

Not applicable.

\section{Funding}

Not applicable.

\section{Publisher's Note}

Springer Nature remains neutral with regard to jurisdictional claims in published maps and institutional affiliations.

Received: 4 January 2019 Accepted: 20 February 2019

Published online: 11 March 2019

\section{References}

1. Focsa M. Scoarte romanesti, catalog, Muzeul de Arta Populara (Romanian carpets, catalogue, Museum of Folk Art), Bucuresti. 1970.

2. Stoica G. Interiorul locuintei romanesti (The interior of the Romanian dwelling), Bucuresti. 1973. p. 27-34.

3. Formagiu HM. Portul popular din Romania, catalog, Muzeul de Arta Populara (The Romanian popular costume, catalogue, Museum of Folk Art), Bucuresti. 1974.

4. Stoica G, Doaga A. Interioare romanesti. Tesaturi si cusaturi decorative (Romanian interiors. Decorative weavings and sewings), Bucuresti. 1977

5. Zaharia F. Textile tradiționale din Transilvania. Tehnologie și estetică (Traditional textiles from Transylvania. Technology and Aesthetics), Complexul Muzeal Bucovina Suceava. 2008.

6. Stoica G (ed). De la fibra la covor (From fibre to carpet), Ed. Fundatiei Culturale Romane, Bucuresti. 1999.

7. Petroviciu I, Wouters J. Analysis of natural dyes from romanian 19th-20th century ethnographical textiles by DAD-HPLC, dyes in history and archaeology 18, archetype. 2002. p. 57-62.

8. Petroviciu I. Liquid chromatography as analytical technique in the characterisation of natural dyes and organic pigments in museum objects, PhD thesis, University of Bucharest. 2011.

9. Pamfile T, Lupescu M. Cromatica poporului român. București: Socec \& C. Sfetea; 1914.

10. Bernath AG. De la constituirea colectiilor sibiene pâna la cele mai actuale abordări de conservare preventive (From the creation of the Sibiu collections to the most current preventative preservation approaches), PhD thesis, University Lucian Blaga Sibiu. 2013. p. 92.

11. Marinescu M. Arta Populară Românească. Tesături decorative (Romanian Popular Art. Decorative Tissues), Ed. Dacia. 1975. p. 22-3.

12. Schoeser M. World textiles: a concise history. London: Thames \& Hudson; 2003. p. 44

13. Brunello F. The art of dyeing in the history of mankind, Neri Pozza, Vicenza. 1973.

14. Cardon D. Natural dyes - sources, tradition, technology, science. London: Archetype Publications; 2007.

15. Hofenk de Graaff JH. The colourful past. origins, chemistry and identification of natural dyestuffs. London: Abegg Stiftung, Archetype Publications; 2004. p. 141-54.

16. Wouters J. HPLC of antraquinones: analysis of plant and insect extracts and dyed textiles. Stud Conserv. 1985;30:119-28.

17. Wouters J. Dye analysis of florentine borders of the 14 th to 16 th centuries. Dyes History Archaeol. 1995;15:48-58.

18. Quye A, Wouters J. An application of HPLC to the identification of natural dyes. Dyes History Archaeol. 1991;10:17-21.

19. Wouters J, de Craeker G. Analysis of dyes and technique of a 20thcentury Iranian carpet from the city of Nain. Dyes History Archaeol. 1992;11:38-46.

20. Wouters J. Dye analysis in a broad perspective: a study of 3rd- to 10thcentury coptic textiles from Belgian private collections. Dyes History Archaeol. 1994;13:38-45.

21. Ackacha MA, Poltec-Pawlak K, Jarosz M. Identification of anthraquinone coloring matters in natural red dyestuffs by HPLC with ultraviolet and electrospray mass spectrometric detection. J Sep Sci. 2003;26:1028-34.

22. Karapanagiotis I, Minopoulou E, Valianou L, Daniilia S, Chryssoulakis Y. Investigation of the colourants used in icons of the Cretan school of iconography. Analitica Chimica Acta. 2009;647:231-42.

23. Trojanowicz M, Orska-Gawrys O, Surowiec I, Szostek B, Urbaniak-Walczak $\mathrm{K}$, Kehr J, Wrobel M. Chromatographic investigation of dyes extracted from coptic textiles from the national museum in Warsaw. Stud Conserv. 2004;49:115-30.

24. Szostek B, Orska-Gawrys J, Surowiec I, Trojanowicz M. Investigation of natural dyes occurring in historical Coptic textiles by high-performance liquid chromatography with UV-Vis and mass spectrometric detection. J Chromatogr A. 2003;1012:179-92.

25. Surowiec I, Szostek B, Trojanowicz M. HPLC-MS of anthraquinoids, flavonoids and their degradation products in analysis of natural dyes in archaeological objects. J Sep Sci. 2007;30:2070-9.

26. Peggie DA, Hulme AN, McNab H, Quye A. Towards the identification of characteristic minor components from textiles dyed with weld (Reseda luteola L.) and those dyed with Mexican cochineal (Dactylopius coccus Costa). Microchemica Acta. 2008;162:371-80.

27. Trolen L, Phillips A, Peggie D, Barran P, Hulme A. Historical textile dyeing with Genista tinctoria L.: a comprehensive study by UPLC-MS/MS analysis. Anal Methods. 2014;6(22):8915-23.

28. Serrano A, van Bommel M, Hallett J. Evaluation between ultrahigh pressure liquid chromatography and high-performance liquid chromatography analytical methods for characterizing natural dyestuffs. J Chromatogr A. 2013:1318:102-11.

29. Petroviciu I, Albu F, Medvedovici A. LC/MS and LC/MS/MS based protocol for identification of dyes in historic textiles. Microchem J. 2010;95:247-54.

30. Petroviciu I, Albu F, Cretu I, Virgolici M, Medvedovici A. Investigation of natural dyes in 15th c. documents seal threads from the Romanian Academy Library, by LC-DAD-MS (triple quadrupole). J Cult Heritage. 2017;28:164-71.

31. Zhang X, Laursen RA. Development of mild extraction methods for the analysis of natural dyes in textiles of historical interest using LC-diode array detector-MS. Anal Chem. 2005;77:2022-5.

32. Wouters J, Grzywacz CM, Claro A. A comparative investigation of hydrolysis methods to analyze natural organic dyes by HPLC-PDA nine methods, twelve biological sources, ten dye classes, dyed yarns, pigments and paints. Stud Conserv. 2011:56(3):231-49.

33. de Keijzer M, van Bommel MR, Keijzer RH, Knaller R, Oberhumer E. Indigo carmine: understanding a problematic blue dye. Stud Conserv. 2012;57(S1):87-95.

34. Hulme A, McNab H, Peggie D, Quye A. The chemical characterisation by PDA HPLC and HPLC ESI MS of aged and unaged fibre samples dyed with 
sawwort (Serratula tinctoria L.). In: Kirby J, editor. The diversity of dyes in history and archaeology. 2017. p. 374-82.

35. Peggie D. The development and application of analytical methods for the identification of dyes on historical textiles, PhD thesis, University of Edinburgh. 2006

36. Nowik W. The possibility of differentiation and identification of red and blue 'soluble' dyewoods: determination of species used in dyeing and chemistry of their dyestuffs. Dyes History Archaeol. 2001;16(17):129-44.

37. Hulme AN, McNab H, Peggie DA, Quye A. Negative ion electrospray mass spectrometry of neoflavonoids. Phytochemistry. 2005;66:2766-70.

38. Petroviciu I, Vanden Berghe I, Cretu I, Albu F, Medvedovici A. Identification of natural dyes in historical textiles from Romanian collections by LC-DAD and LC-MS (single stage and tandem MS). J Cult Heritage. 2012:13:89-97.
39. Peggie D, Kirby J, Poulin J, Genuit W, Romanuka J, Wills D, De Simone A, Hulme A. Historical mystery solved: a multi-analytical approach to the identification of a key marker for the historical use of brazilwood (Caesalpinia spp.) in paintings and textiles. Anal Methods. 2018;10:617.

40. Wouters J, Verhecken A. The coccid insect dyes: HPLC and computerized diode-array analysis of dyed yarns. Stud Conserv. 1989;34:189-200.

41. Wouters J, Verhecken A. The scale insect dyes (Homoptera: Coccoidea): species recognition by HPLC and diode-array analysis of the dyestuffs. Annales de la Société Entomologique de France. 1989;25(4):393-410.

42. Serrano $A$, van den Doel $A$, van Bommel M, Hallett J, Joosten I, van den Berg KJ. Investigation of crimson-dyed fibres for a new approach on the characterization of cochineal and kermes dyes in historical textiles. Anal Chim Acta. 2015;897:116-27.

\section{Submit your manuscript to a SpringerOpen ${ }^{\circ}$ journal and benefit from:}

- Convenient online submission

- Rigorous peer review

- Open access: articles freely available online

- High visibility within the field

- Retaining the copyright to your article

Submit your next manuscript at $\boldsymbol{\nabla}$ springeropen.com 